\title{
A MODEL OF THE MOMENT CURVATURE RELATION FOR RC BEAMS STRENGTHENED WITH PRESTRESSED CFRP LAMINATES
}

\begin{abstract}
J. KORENTZ ${ }^{1}$
The paper presents an analysis of the behaviour of bent reinforced concrete beams strengthened with CFRP laminates fixed with adhesive before and after unloading, and more importantly, an analysis of the work of reinforced concrete beams strengthened with pre-stressed CFRP laminates fixed with adhesive. The analyses were based on a moment-curvature model prepared by the author for reinforced concrete beams strengthened under load with pre-stressed CFRP laminates. The model was used to determine the effect of compression with CFRP laminates and their mechanical properties on the effectiveness of strengthening the reinforced concrete beams analysed in this study.
\end{abstract}

Keywords: CFRP laminates, curvature, compression, bending moment, RC beam, strengthening

\section{INTRODUCTION}

Structural reinforcements are often applied during the modernization or renovation of buildings. Their aim is to restore the original load capacity of the structure or to increase its load capacity because new heavier loads are expected.

In most cases reinforced concrete structures are strengthened with CFRP laminates. Steel bars and profiles as well as tendons are also used. It is also possible to use GFRP and AFRP laminates and mats. These materials have very different mechanical properties. The techniques used to strengthen reinforced concrete elements include: increasing the dimensions of concrete cross-sections, using additional tensile reinforcement, bonding with steel profiles, using FRP laminates - externally

\footnotetext{
${ }^{1}$ Assoc. Prof. PhD. Eng., University of Zielona Góra, Faculty of Civil Engineering, Architecture and Environmental Engineering, ul. Licealna 9, 65-417 Zielona Góra, Poland, e-mail: j.korentz@ib.uz.zgora.pl, ORCID: 0000-0002$1521-8681$
} 
bonded (EB) or near surface mounted (NSM), changing the static scheme, and strengthening with active reinforcement $[10,25]$. The methods used to strengthen reinforced concrete beams include: strengthening before loading, strengthening under load, strengthening after unloading, compressing with adhesive or non-adhesive repair materials and assembly compression.

Most available experimental studies have focused on strengthening before loading $[6,15]$. There are far fewer experimental tests on elements strengthened under load, elements strengthened after unloading, or elements strengthened by compression with repair material [14, 16, 19, 21, 22].

However, in practice, we deal with a situation where we strengthen existing structural elements that have been used for many years, already under load and with permanent deformations. Differences between the behaviour of structural elements strengthened with various repair materials and the abovementioned strengthening methods are important and should be taken into account in the design of strengthening for reinforced concrete beams strengthened in flexure [11].

If we know static equilibrium paths for different strengthening methods, we can choose the right methods to achieve the intended goal and to ensure that the strengthened element will behave in the expected way and serve its purpose in the object. The paper presents a model of the momentcurvature relation for reinforced concrete beams strengthened under load by compression with CFRP laminates fixed with adhesive.

\section{BEHAVIOUR OF A STRENGTHENED RC BEAMS}

Fig. 1 shows the idealization of the relation between the bending moment $M$ and the curvature $\varphi$ in a cross-section for three reinforced concrete beams: a beam without strengthening- line OCYU, a beam strengthened before loading without tension - line $\mathrm{OC}_{\mathrm{Lo}} \mathrm{Y}_{\mathrm{Lo}} \mathrm{U}_{\mathrm{Lo}}$ and a beam strengthened under load with prestressed CFRP laminates - line $\mathrm{OCO}_{c} \mathrm{O}_{\mathrm{L}} \mathrm{Y}_{\mathrm{L}} \mathrm{U}_{\mathrm{L}}$.

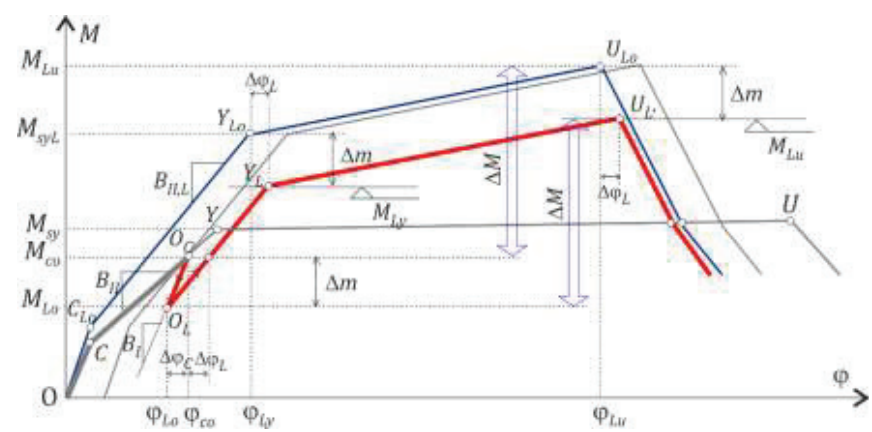

Fig. 1:Relation between the moment $\mathrm{M}$ and the curvature $\varphi$ for: $\mathrm{RC}$ beam (OCYU), $\mathrm{RC}$ beam strengthened with CFRP laminates before loading $\left(\mathrm{OC}_{\mathrm{Lo}} \mathrm{Y}_{\mathrm{Lo}} \mathrm{U}_{\mathrm{LO}}\right)$ and $\mathrm{RC}$ beam strengthened under load with prestressed CRFP laminates $\left(\mathrm{OCO}_{\mathrm{c}} \mathrm{O}_{\mathrm{L}} \mathrm{Y}_{\mathrm{L}} \mathrm{U}_{\mathrm{L}}\right)$. 
The points marked with the letter $\mathrm{C}$ indicate the appearance of cracks on the cross section, the points marked with the letter $\mathrm{Y}$ indicate the yield point of the beam reinforcement, and the points marked with the letter $U$ indicate when the bearing capacity of the beam is exceeded. The loadbearing capacity of beams strengthened with adhesive laminates is most often exceeded as a result of the delamination of the laminates $[15,21]$.

An initially strained beam strengthened with prestressed CFRP laminates is subjected to detailed analysis. There are known technologies for tensioning composite laminates and fixing them to reinforced concrete beams with adhesive [13]. An initially strained beam strengthened with prestressed CFRP laminates is subjected to detailed analysis.

The strengthening is applied when the load causing the bending moment $M_{c o}$ acts on the beams. The purpose of the strengthening is to increase the bearing capacity of the cross-section from $M_{s y}$ to $M_{L u}$. This means that when the strengthening has been completed (points $O_{c}$ and $O_{L}$ ), the bending moment caused by the new expected loads may increase to $\Delta M$. The behaviour of the loaded reinforced concrete cross-section before strengthening is illustrated by line $O C O_{c}$. Section $O_{c} O_{L}$ of the static equilibrium path is the stage of prestressing the CFRP laminates, which is accompanied by a reduction in the beam's strain by the value of the bending moment $\Delta \mathrm{m}$ induced by compressive force. At the same time, unloading the beam is accompanied by a reduction in its curvature by $\Delta \varphi$. Line $O_{L} Y_{L} U_{L}$ is the working phase of the beam after strengthening under the expected additional new loads.

\section{MODELS OF THE MOMENT - CURVATURE RELATION}

There have been attempts to analytically $[1,2,4,8,10,12,17,18]$ and numerically $[5,7,23]$ analyse the behaviour of reinforced concrete beams strengthened with CFRP laminates. However, there is an insufficient number of methods for analysing the behaviour of reinforced concrete beams strengthened with presteressed CFRP laminates under load. This study is an attempt to fill this gap. Their aim was to determine the possibility of rational evaluation of the work of strengthened reinforced concrete beams over the entire load range. One of the methods for assessing the behaviour of structural elements are static equilibrium paths [3], which can include, among others, the relation between the bending moment and the curvature of the cross-section.

In order to construct a moment-curvature relation model for a reinforced concrete beam strengthened with prestressed CFRP laminates, it is necessary to determine the coordinates of characteristic points of this model. These will be determined on the basis of a model of the 
behaviour of the reinforced concrete beam [9] and a model of the behaviour of the reinforced concrete beam strengthened before loading [8].

\subsection{REINFORCED CONCRETE BEAM WITHOUT STRENGTHENING}

In Fig.1, broken line $O C Y U$ illustrates the behaviour of a reinforced concrete beam in the entire load range. The curvature at the time when the beam started to crack $\xi_{c r}$ and the dimensionless bending moment $m_{c r}$ (point $\mathrm{C}$ in Fig.1) can be expressed with the following relations:

$$
\begin{gathered}
\varphi_{c r}=\frac{f_{c t} / E_{c}}{\mathrm{~d}\left(1+\beta_{1}-\xi_{c r}\right)} \\
m_{c r}=\frac{M_{c r}}{f_{c t} b d^{2}}=\frac{1}{1+\beta_{1}-\xi_{c r}}\left\{\begin{array}{c}
\frac{\left(1+\beta_{1}\right)^{3}}{12}+\left(1+\beta_{1}\right)\left[\xi_{c r}-\frac{1}{2}\left(1+\beta_{1}\right)\right]^{2}+ \\
+n \rho_{1}\left[\left(1-\xi_{c r}\right)^{2}+p\left(\xi_{c r}-\beta_{2}\right)^{2}\right]
\end{array}\right\}
\end{gathered}
$$

where: $\xi_{\mathrm{cr}}$ is the relative height of the compressed zone expressed with the relation:

$$
\xi_{c r}=\frac{0.5\left(1+\beta_{1}\right)^{2}+n \rho_{1}\left(1+\beta_{2} p\right)}{\left(1+\beta_{1}\right)+n \rho_{1}(1+p)}
$$

where: $f_{c t}$ is the concrete tensile strength, $E_{c}$ is the concrete elastic modulus, $E_{s}$ is the steel elastic modulus and $\beta_{1}=a_{1} / d, \beta_{2}=a_{2} / d, \rho_{1}=A_{s l} / b d, \rho_{2}=A_{s 2} / b d, p=\rho_{1} / \rho_{2}, n=E_{s} / E_{c}$ are parameters of the cross-section under analysis.

The curvature $\varphi_{s y}$ and the dimensionless bending moment $m_{s y}$ at the yield point of the reinforcement (point $\mathrm{Y}$ in Fig.1) are described with the relations:

$$
\begin{gathered}
\varphi_{s y}=\frac{\varepsilon_{s y}}{\mathrm{~d}\left(1-\xi_{s y}\right)} \\
m_{s y}=\frac{M_{s y}}{f_{s y} b d^{2}}=\frac{1}{2 n} \frac{\xi_{s y}^{2}}{1-\xi_{s y}}\left(1-\frac{1}{3} \xi_{s y}\right)+\frac{\xi_{s y}-\beta_{2}}{1-\xi_{s y}} p \rho_{1}\left(\xi_{s y}-\beta_{2}\right)
\end{gathered}
$$

where the relative height of the compressed zone $\xi_{s y}$ is expressed with the relation:

$$
\xi_{s y}=\sqrt{n^{2} \rho_{1}^{2}(1+p)^{2}+2 n \rho_{1}\left(\beta_{2} p+1\right)}-n \rho_{1}(1+p)
$$


If the bending moments and curvatures at characteristic points of the model are known, the stiffness in bending of the non-cracked reinforced concrete cross section $B_{I}$ and of the cracked cross-section $B_{I I}$ can be expressed as follows:

$$
\begin{gathered}
B_{I}=\frac{M_{c r}}{\varphi_{c r}} \\
B_{I I}=\frac{M_{s y}-M_{c r}}{\varphi_{s y}-\varphi_{c r}}
\end{gathered}
$$

\subsection{REINFORCED CONCRETE BEAM STRENGTHENED BEFORE LOADING}

Similarly, it is possible to describe characteristic points of the moment-curvature model for a reinforced concrete beam strengthened before loading (the line $O C_{L o} Y_{L o} U_{L o}$ in Fig.1). The curvature at the time when the beam started to crack $\varphi_{c r L}$, the dimensionless bending moment $m_{c r L}$ (point $\mathrm{C}_{\mathrm{Lo}}$ in Fig.1) and the relative height of the compressed zone $\xi_{c r L}$ can be expressed by the following relations:

$$
\varphi_{c r L}=\frac{f_{c t} / E_{c}}{d\left(1+\beta_{1}-\xi_{c r L}\right)}
$$

$$
\begin{gathered}
m_{c r L}=\frac{M_{c r L}}{f_{c t} b d^{2}}=\frac{1}{1+\beta_{1}-\xi_{c r L}}\left\{\begin{array}{c}
\frac{\left(1+\beta_{1}\right)^{3}}{12}+\left(1+\beta_{1}\right)\left[\xi_{c r L}-\frac{1}{2}\left(1+\beta_{1}\right)\right]^{2}+ \\
+n \rho_{1}\left[\left(1-\xi_{c r L}\right)^{2}+p\left(\xi_{c r L}-\beta_{2}\right)^{2}\right]+n_{L} \rho_{L}\left(1+\beta_{L}-\xi_{c r L}\right)
\end{array}\right\} \\
\xi_{c r L}=\frac{0.5\left(1+\beta_{1}\right)^{2}+n \rho_{1}\left(1+\beta_{2} p\right)+n_{L} \rho_{L}\left(1+\beta_{L}\right)}{\left(1+\beta_{1}\right)+n \rho_{1}(1+p)+n_{L} \rho_{L}}
\end{gathered}
$$

where: $\beta_{L}=a_{L} / d, \rho_{L}=A_{L} / b d, n_{L}=E_{L} / E_{c}$ are parameters of the cross-section under analysis.

The curvature $\varphi_{s y L}$, the dimensionless bending moment $m_{s y L}$ and the relative height of the compressed zone $\xi_{s y L}$ at the yield point of the beam reinforcement (point $Y_{L o}$ ) are expressed with the following relations:

$$
\varphi_{s y L}=\frac{\varepsilon_{s y}}{\mathrm{~d}\left(1-\xi_{s y L}\right)}
$$




$$
\begin{gathered}
m_{s y L}=\frac{M_{s y L}}{f_{s y} b d^{2}}=\frac{1}{2 n} \frac{\xi_{s y L}^{2}}{1-\xi_{s y L}} \frac{2}{3} \xi_{s y L}+\frac{\xi_{s y L}-\beta_{2}}{1-\xi_{s y L}} p \rho_{1}\left(\xi_{s y L}-\beta_{2}\right)+\rho_{1}\left(1-\xi_{s y L}\right)+ \\
+\frac{n_{L}}{n} \frac{1+\beta_{L}-\xi_{s y L}}{1-\xi_{s y L}} \rho_{L}\left(1+\beta_{L}-\xi_{s y L}\right) \\
\xi_{s y L}=\sqrt{n^{2} \rho_{1}^{2}(1+p)^{2}+2\left[n \rho_{1}\left(\beta_{2} p+1\right)+n_{L} \rho_{L}\left(1+\beta_{L}\right)\right]}-\left[n \rho_{1}(1+p)+n_{L} \rho_{L}\right]
\end{gathered}
$$

The curvature $\varphi_{L u}$, the dimensionless boundary moment $m_{L U}$ and the relative height of the compressed zone $\xi_{L u}$ (point $U_{L o}$ ) in relation to the boundary deformations in the strengthening reinforcement $\varepsilon_{L u}$ are described by the formulas:

$$
\begin{gathered}
\varphi_{L u}=\frac{\varepsilon_{L u}}{\mathrm{~d}\left(1+\beta_{\mathrm{L}}-\xi_{L u}\right)} \\
m_{L u}=\frac{M_{L u}}{f_{s y} b d^{2}}=\rho_{1}\left(1-\frac{\lambda \xi_{L u}}{2}\right)+\rho_{2}\left(\frac{\lambda \xi_{L u}}{2}-\beta_{2}\right)+\rho_{L} \frac{f_{L}}{f_{s y}}\left(1+\beta_{L}-\frac{\lambda \xi_{L u}}{2}\right) \\
\xi_{L u}=\frac{1}{\lambda \eta}\left(\omega_{1}(1-p)+\omega_{L}\right)
\end{gathered}
$$

where: $\omega_{I}=\rho_{I} f_{s y} / f_{c o}, \omega_{L}=\rho_{L} f_{s y} / f_{L}$ are the mechanical ratio of the tensile reinforcement and the mechanical ratio of the strengthening reinforcement respectively, $\lambda$ - the factor defining the effective height of the compression zone, $\eta$ - the factor defining effective strength.

Stiffness in bending of the non-cracked strengthened cross-section $B_{I L}$ and of the cracked crosssection $B_{I I L}$ can be expressed as follows:

$$
\begin{gathered}
B_{I L}=\frac{M_{c r L}}{\varphi_{c r L}} \\
B_{I I L}=\frac{M_{s y L}-M_{c r L}}{\varphi_{s y L}-\varphi_{c r L}}
\end{gathered}
$$

\subsection{REINFORCED CONCRETE BEAM STRENGTHENED UNDER LOAD WITH PRESTRESSED CFRP LAMINATES}

Line $O C O_{C} O_{L} Y_{L} U_{L}$ in Fig. 1 illustrates the behaviour of a reinforced concrete beam strengthened under load with CFRP laminates. The maximum possible load level of the concrete cross-section before compression expressed by its bend strength is $M_{s y}$. The purpose of strengthening is to 
increase the load capacity of the cross-section to $M_{L u}$. The strengthening is applied when the crosssection load level causes the bending moment $M_{c o}$. If the strengthening were applied traditionally, with laminates without prestressing, the load capacity would increase to $\Delta M$. As a result of prestressing the strengthening laminates the cross-section is relieved. A negative bending moment $\Delta m$ is introduced and as a result of the combined action of the load and the prestressing force, the load level of the cross-section is determined by the moment $M_{L o}$. In this case, the load capacity of the cross-section will increase by the same value, i.e. $\Delta M$. This is because the load capacity of the strengthened reinforced concrete beams is exceeded when the laminates start to delaminate, which takes place when composite laminates reach a specific level of deformation [15, 24].

The curvature and the bending moment of the beam cross-section at the time when it starts to crack before strengthening are defined with the relations (3.1) and (3.2), respectively. The strain level of the cross-section at the moment of strengthening (point $\mathrm{O}_{c}$ ) depends on the load and is determined by the bending moment $M_{c o}$. The curvature $\varphi_{c o}$ corresponding to the bending moment $M_{c o}$ can be determined from the relation:

$$
\varphi_{c o}=\varphi_{c r}+\frac{1}{B_{I I}}\left(M_{c o}-M_{c r}\right)
$$

where: $B_{I I}(3.8)$ is the stiffness in bending of the cracked reinforced concrete cross-section.

While the composite laminates are being prestressed some of the load is removed from the crosssection; the bending moment acting on the cross-section decreases by $\Delta m$ and the curvature decreases by $\Delta \varphi$ (point $\mathrm{O}_{\mathrm{L}}$ ). When the prestressing of the laminates ends, the bending moment $M_{L o}$ depends on the value of the compressive force $S_{L}$ and amounts to:

$$
M_{L o}=M_{c o}-\Delta m=M_{c o}-S_{L}\left(d+a_{L}-\xi_{c r} d\right)
$$

and the curvature after the prestressing of the laminates $\varphi_{L o}$ is:

$$
\varphi_{L o}=\varphi_{c o}-\Delta \varphi=\varphi_{c o}-\frac{1}{B_{I}}\left(M_{c o}-M_{L o}\right)
$$

where: $B_{I}(3.7)$ is the bending strength of the non-cracked reinforced concrete cross-section. 
At the yield point of the existing reinforcement, the bending moment $M_{\mathrm{Ly}}$ and the curvature $\varphi_{L y}$ (point $Y_{L}$ ) are described by the relations:

$$
\begin{gathered}
M_{L y}=M_{s y L}-\Delta m \\
\varphi_{L y}=\varphi_{s y L}+\Delta \varphi_{L}=\varphi_{s y L}+\left(\frac{\varphi_{s y L-\varphi_{c r L}}}{M_{s y L}-M_{c r L}}\left(M_{c o}-M_{L o}\right)-\Delta \varphi_{c}\right)
\end{gathered}
$$

The bending moment $M_{\text {Lue }}$ and the curvature $\varphi_{\text {Lue }}$ at the moment when the load capacity is exceeded (point $U_{L}$ ) can be determined from the formulas:

$$
\begin{gathered}
M_{L u e}=M_{L u}-\Delta m \\
\varphi_{L u e}=\varphi_{L u}+\Delta \varphi_{L}=\varphi_{L u}+\left(\frac{\varphi_{s y L-\varphi_{c r L}}}{M_{s y L}-M_{c r L}}\left(M_{c o}-M_{L o}\right)-\Delta \varphi_{c}\right)
\end{gathered}
$$

The formulas presented above make it possible to determine five characteristic points of the moment-curvature relation for a rectangular reinforced concrete beam with any type of reinforcement strengthened with prestressed composite laminates.

\section{EXAMPLE OF AN ANALYSIS}

Rectangular reinforced concrete beams with the dimensions $30 \mathrm{~cm} \times 50 \mathrm{~cm}$ were analysed. The compressive strength of concrete is $f_{c o}=30 \mathrm{MPa}$ and elastic modulus is $E_{c}=32 \mathrm{GPa}$. The reinforcement is made of steel with the yield point $f_{s y}=400 \mathrm{MPa}$ and elastic modulus $E_{s}=200 \mathrm{GPa}$. The tensile reinforcement consists of five bars with a diameter of $20 \mathrm{~mm}$, and the reinforcement in the compressed zone consists of two bars with a diameter of $12 \mathrm{~mm}$.

Two cases of strengthening with prestressed CFRP laminates are considered: strengthening with high modulus strips (cross-section F1) and strengthening with low modulus strips (cross-sections F2). The geometric data for the cross-sections and the mechanical properties of the laminates are presented in Fig.2. Fig. 2 shows the graph of the relation between the bending moment $M$ and the curvature $\varphi$ for beams strengthened with prestressed laminates with various mechanical properties fixed with adhesive onto their lower edge (beam F1 and F2). Moreover, this figure also shows 
graphs plotted for beams strengthened with the same laminates before loading but without prestressing.

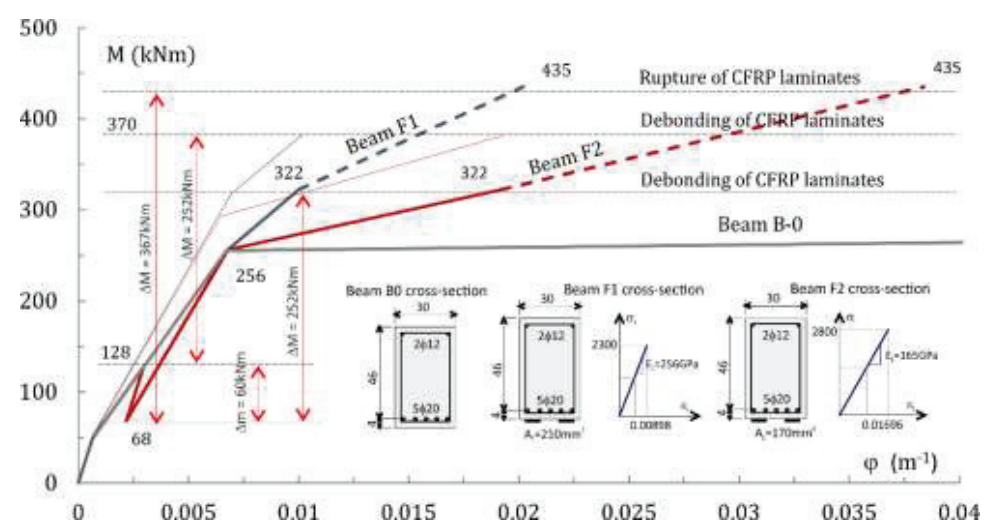

Fig. 2. Moment-curvature relation for RC beam F1 and F2 strengthened with prestressed CFRP laminates.

The load-bearing capacity of beam B- 0 a prior to strengthening is $256 \mathrm{kNm}$. It is assumed that the loads will increase, so it is necessary to increase the load capacity by about $40 \%$, i.e. to $\mathrm{M}=$ $370 \mathrm{kNm}$. Moreover, it is assumed that before strengthening the beam, its load will be reduced to $50 \%$ of the previous total load, so the initial bending moment can be estimated at $\mathrm{M}_{\mathrm{o}}=128 \mathrm{kNm}$. This means that after strengthening it will be possible to apply a load that can cause an increase in the bending moment $\Delta M=370 \mathrm{kNm}-128 \mathrm{kNm}=252 \mathrm{kNm}$. As a result of the analysis of the ultimate boundary states, the necessary surface area of the laminates $A_{L}$ was determined for two parameters of the laminates used (cf. Fig. 2). In the calculations, the boundary deformation of the laminates at the moment of delamination was adopted as $50 \%$ of their maximum deformation. The stresses in the laminates at the moment of prestressing constitute $50 \%$ of their bearing capacity, which enables the application of a compressive force of $240 \mathrm{kN}$. Then, the prestressing force results in a bending moment $\Delta m=60 \mathrm{kNm}$.

The results of the calculations are shown in Fig.2. Strengthening the beam with the use of prestressed CFRP laminates increases its load-bearing capacity as much as strengthening it with the same laminates but without prestressing. Beams strengthened with prestressed laminates can bear an additional external load, which can cause an increase in the bending moment $\Delta M$ of about $255 \mathrm{kNm}$. The load-bearing capacity of the beam is exceeded as a result of the debonding of the laminates. However, if the laminates are glued into the reinforcement cover, the load capacity of the 
beam is exceeded as a result of the rupture of the laminates [13]. If the load capacity of the crosssection is exceeded in this way, there can be a much higher increase in the bending moment $\Delta M$ caused by additional loads amounting to $367 \mathrm{kNm}$.

The analyses indicate that the effectiveness of strengthening reinforced concrete beams by applying prestressed CFRP laminates is the same as the effectiveness of using the same laminates without prestressing. The effectiveness of strengthening with CFRP laminates can be considerably increased by using adhesive strips. Although the model $M-\varphi$ for a reinforced concrete beam [9] and the model $M-\varphi$ for a beam strengthened before loading [8] have been experimentally verified, the momentcurvature relation model for a beam reinforced under load with prestressed CFRP laminates and the results obtained on its basis also require experimental verification.

\section{Conclusions}

At present, a large number of existing structures are strengthened in Poland including also reinforced concrete structures. This is a result of modernization or the necessity to restore their original load capacity. In practice, a variety of strengthening methods and techniques are used that make use of repair materials with very different physical and mechanical properties.

The static equilibrium paths that are presented and the resulting moment-curvature relation model for a reinforced concrete beam strengthened with CFRP laminates and also for a beam strengthened with non-prestressed laminates can be a basis for designing methods of calculating deformations of reinforced concrete beams. The models presented in this study can also be used for predicting the behaviour of strengthened reinforced concrete beams in the entire load range

\section{REFERENCES}

1. Achintha P.M.M., Burgoyone C.J., "Moment-curvature and strain energy of beams with external fiber-reinforced polymer reinforcement”, ACI Structural Journal, 106(1), pp. 20-29, 2009.

3. Bakis C.E., Bank L.C., Brown V,L., Cosenza E., Davalos J.F., Lesko J.J., Machida A., Rizkalla S.H., Triantafillou T.C., "Fiber-reinforced polymer composites for construction - State-of-the-arte review", Journal of Composites for Construction 6(2), pp.73-87, 2002.

4. Biegus A., "Limit load capacity of steel bar structures" (in Polish), PWN, Warsaw, 1997.

5. "Externally bonded FRP reinforcement for RC structures", Technical Report, Fib Bulletin, No 14, Lausanne, 2001.

6. Głodkowska W., Ruchwa M., "Static analysis of reinforced concrete beams strengthening with CFRP composites", Archive of Civil Engineering, 56(2), pp.111-122, 2010.

7. Kamińska M.E., Kotynia R., "Experimental research on RC beams strengthened with CFRP strips", Zeszyt 9 , Wydawnictwo Katedry Budownictwa Betonowego Politechniki Łódzkiej, Łódź, 2000.

8. Korentz J., "Effectiveness technique of strengthening of reinforced concrete beams" (in Polish), Renowacja budynków i obszarów zabudowanych, t.5, pp.301-308, 2009. 
9. Korentz J., "Moment - curvature relationship for strengthening reinforced concrete cross-section" (in Polish), Proceedings of the Conference Konstrukcje Zespolone, Poland, Zielona Góra, pp.117-124, 2011.

10. Korentz J., "Moment - curvature relationship for reinforced concrete beams, ductility assessment" (in Polish), Drogi Lądowe Powietrzne Wodne, 6, pp.23-30, 2010.

11. Korentz J., "A method for calculation the deflection of reinforced concrete beams strengthening with FRP" (in Polish), Zeszyty Naukowe Politechniki Rzeszowskiej, 3/2011, pp.143-159, 2011.

12. Korentz J., "Static equilibrium paths for CFRP strengthened reinforced concrete beams" (in Polish), Czasopismo Inżynierii Lądowej, Środowiska i Architektury, XXXIV(64), pp.213-222, 2017.

13. Korentz J., "A model of the moment-curvature relationship for reinforced concrete beams strengthened under load", Proceedings of the fib Symposium 2019: Concrete - Innovations in Materials, Design and Structures, Kraków, Poland, pp.842-848, 2019

14. Kotynia R., "Bond methods of strengthening reinforced concrete structures with pretensioned composite polymers", Przegląd Budowlany, 7-8, pp.49-56, 2015.

15. Kotynia R., Przygocka M., Lasek K, "Preloading effect on strengthening efficiency of RC beams strengthened with pretensioned CFRP strips", Konstrukcje betonowe i metalowe, Wydawnictwo Uczelniane UT-P w Bydgoszczy, pp.47-54, 2016.

16. Kotynia R., Kamińska M.E., "Ductility and failure mode of RC beams strengthened for flexure with CFRP", Zeszyt 13, Wydawnictwo Katedry Budownictwa Betonowego Politechniki Łódzkiej, Łódź, 2003.

17. Łagoda M., "Element strengthening by stressed composite strip-an example of experimental investigation", Archives of Civil Engineering, 50(4), pp.599-623, 2004.

18. Moein R.S., Tasnimi, A.A., "An analytical model for FRP debonding in strengthened RC beams under monotonic and cyclic loads", International Journal of Concrete Structures and Materials, 10 (4), pp. 499-511, 2016.

19. Mota, C., Alminar, S. \& Svecova, D., "Critical review of deflection formulas for FRP-RC members", Journal of Composites for Construction, ASCE, 10(3), pp. 183-194, 2006.

20. Pelegrino C., Modena C., "Flexural strengthening of real-scale RC and PRC beams with and-anchored pretensioned FRP laminates”, ACI Structural Journal 106(3), pp.319-328, 2009.

21. Runkiewicz L., "Strengthening of reinforced concrete constructions" (in Polish), ITB, Warsaw, 2011.

22. Wang, W., Li, G., "Experimental study and analysis of RC beams strengthened with CFRP laminates under sustaining load", International Journal of Solids and Structures, 43, pp. 1327-1387, 2005.

23. Weichen, X., Yuan T., Lei Z., "Flexural response prediction of reinforced concrete beams strengthening with presatressed CFRP plates”, Composite Stuctures, 92(3), pp. 612-622, 2010.

24. Seręga S., Kotynia R., Lasek K., "Computational analysis of RC beams strengthening with prestressed CFRP laminates" (in Polish), Czasopismo Inżynierii Lądowej, Środowiska i Architektury, XXXIII(63), pp.279-287, 2016.

25. Smith S.T., Teng J.G., "FRP-strengthened RC beams. I: review of debonding strength models", Engineering Structures, 24, pp.385-395, 2002.

26. Urban T., "Strengthening of reinforced concrete constructions with traditional methods" (in Polish), PWN, Warsaw, 2015.

\section{LIST OF FIGURES AND TABLES:}

Fig. 1. Relation between the moment $\mathrm{M}$ and the curvature $\varphi$ for: RC beam (OCYU), RC beam strengthened with CFRP laminates before loading $\left(\mathrm{OC}_{\mathrm{Lo}} \mathrm{Y}_{\mathrm{Lo}} \mathrm{U}_{\mathrm{Lo}}\right)$ and $\mathrm{RC}$ beam strengthened under load with prestressed CRFP laminates $\left(\mathrm{OCO}_{\mathrm{c}} \mathrm{O}_{\mathrm{L}} \mathrm{Y}_{\mathrm{L}} \mathrm{U}_{\mathrm{L}}\right)$.

Rys. 1. Zależność moment M krzywizna $\varphi$ dla: belki żelbetowej (OCYU), belki żelbetowej wzmocnionej taśmami CFRP przed obciążeniem $\left(\mathrm{OC}_{\mathrm{Lo}} \mathrm{Y}_{\mathrm{Lo}} \mathrm{U}_{\mathrm{Lo}}\right)$, belki żelbetowej wzmocnionej naprężonymi taśmami CFRP pod obciążeniem $\left(\mathrm{OCO}_{\mathrm{c}} \mathrm{O}_{\mathrm{L}} \mathrm{Y}_{\mathrm{L}} \mathrm{U}_{\mathrm{L}}\right)$.

Fig. 2. Moment-curvature relation for RC beam F1 and F2 strengthened with prestressed CFRP laminates.

Rys. 2. Zależność moment krzywizna dla belek żelbetowych F1 i F2 wzmocnionych naprężonymi taśmami CFRP. 


\section{MODEL ZALEŻNOŚCI MOMENT - KRZYWIZNA DLA BELEK ŻELBETOWYCH WZMOCNIONYCH NAPRĘŻONYMI TAŚMAMI CFRP}

Keywords: wzmacnianie, taśmy CFRP, moment, krzywizna, sprężenie, belki żelbetowe.

\section{SUMMARY:}

Wzmocnienia konstrukcji dokonuje się w celu przywrócenia im pierwotnej nośności lub zwiększenia ich nośności ze względu na zmianę przeznaczenia obiektu, której towarzyszy wzrost obciążeń. Do wzmocnień konstrukcji żelbetowych najczęściej stosowane są taśmy z włókien węglowych CFRP. Stosowane są też pręty i kształtowniki stalowe, a także sploty. Możliwe jest też stosowanie taśm i mat z włókien szklanych GFRP i aramidowych AFRP. Są to materiały o bardzo różnych właściwościach mechanicznych. Pośród technik stosowanych podczas wzmacniania belek żelbetowych w strefie zginania można między innymi wymienić: zwiększanie wymiarów przekroju betonowego, zastosowanie dodatkowego zbrojenia rozciąganego, spajanie z kształtownikami stalowymi, doklejanie taśm FRP, wklejanie taśm FRP, zmiana schematu statycznego, a także wzmacnianie zbrojeniem aktywnym przez sprężenie. Jeżeli chodzi o metody wzmacniania belek żelbetowych to można wyróżnić: wzmacnianie przed obciążeniem, wzmacnianie pod obciążeniem, wzmacnianie po odciążeniu, sprężenie materiałami naprawczymi przez przyczepność lub bez przyczepności i sprężenie montażowe.

Najwięcej dostępnych badań doświadczalnych poświęconych jest wzmocnieniom wykonywanym przed obciążeniem, badań doświadczalnych elementów wzmacnianych pod obciążeniem, elementów wzmacnianych po odciążeniu, czy też po jego sprężeniu materiałem naprawczym jest znacznie mniej. W praktyce mamy do czynienia z przypadkiem, gdy wzmacniamy istniejące elementy konstrukcyjne eksploatowane od wielu lat, które są już obciążone, a do tego występują już w nich deformacje trwałe. Różnica w zachowaniu się elementów konstrukcyjnych wzmacnianych przy zastosowaniu różnych materiałów naprawczych i wymienionych metod wzmocnienia jest istotna i powinna być uwzględniana w projektowaniu wzmocnień belek żelbetowych w strefie zginania.

Znane są próby analitycznego i numerycznego ujęcia zachowania się belek żelbetowych wzmocnionych także naprężonymi taśmami CFRP, których celem jest możliwość racjonalnej oceny pracy elementów żelbetowych po wzmocnieniu. Jedną z metod oceny zachowania się elementów konstrukcyjnych są ścieżki równowago statycznej. Znajomość ścieżek równowagi statycznej, zależności moment - krzywizna, dla różnych metod wzmocnienia może pozwolić na ich racjonalny wybór tak ażeby osiągnąć zamierzony cel dotyczący pracy wzmacnianego elementu dla projektowanego przeznaczenia obiektu. W artykule zaprezentowano model zależności moment-krzywizna dla przekroju belki żelbetowej wzmocnionej pod obciążeniem doraźnym przez sprężenie taśmami CFRP. W proponowanym modelu zależność moment - krzywizna wyróżnia się trzy fazy pracy: praca belki niezarysowanej, praca belki zarysowanej i praca belki po uplastycznieniu zbrojenia (Rys.1). W celu wyznaczenia modelu zależności moment - krzywizna przekroju żelbetowego wzmocnionego napiętymi taśmami kompozytowymi konieczne jest określenie współrzędnych charakterystycznych punktów tego modelu. Są one określone na podstawie modelu pracy belki żelbetowej i modelu pracy belki żelbetowej wzmocnionej przed obciążeniem. Proponowany model zilustrowano przykładem jego zastosowania w analizie zachowania się dwóch belek wzmocnionych dwoma rodzajami taśm CFRP (Rys.2).

Received 11.08.2019,

Revised 25.11.2019 